\title{
EFFICIENCY OF EU FINANCIAL SUPPORT POLICY FOR DEVELOPMENT OF RURAL ENTREPRENEURSHIP IN POLAND ${ }^{1}$
}

\author{
Adam Wasilewski
}

\section{Summary}

The main research objective was to assess the efficiency and effectiveness, in some theoretical approaches considered as a type of efficiency, of EU financial support affecting the entrepreneurship development in rural areas of Poland.

Descriptive and comparative analysis of basic statistics and Gini coefficient as well as the econometric model of absolute beta convergence were applied as e research methods. The analysis utilised the data from Central Statistical Office, Local Data Bank, for 2004-2013 for 1,529 rural counties.

General conclusion of the paper is that EU financial support had a positive and statistically significant impact on local absolute beta convergence. Moreover, the analyses confirmed that the higher level of support from the EU budget accelerates an increase in the number of private enterprises, micro-enterprises and the number of the employees. It also slows down the processes of growth in the number of the unemployed. However this is the shorttime effect.

Key words: EU policy, public support, efficiency of allocation, SME development, rural areas.

JEL: $D 61, Q 18$

\section{Introduction}

The role of development of non-agricultural activities in the rural areas as well as existing barriers and drivers of this development have caused that the issue has become a subject

1 The paper is a part of research within Multi-annual Programme: "Competitiveness of the Polish food economy in the conditions of globalization and European integration", realised by the Institute of Agriculture and Food Economics - National Research Institute, Warsaw, Poland for the Ministry of Agriculture and Rural Development of Poland.

2 Adam Wasilewski, Ph.D., Assistant Professor, Institute of Agriculture and Food Economics National Research Institute, Swietokrzyska Street no. 20, 00-002 Warsaw, Poland, Phone: +48 2250544 19, E-mail: wasilewski@ierigz.waw.pl

EP 2015 (62) 2 (437-452) 
of interest, and also the influence of different policies. One example is the policy of the European Union, which, through the use of various instruments, both in the context of regional and structural policy, seeks to promote the development of non-agricultural sectors of the economy. The support of the public sector to the private sector constitutes, however, the state's interference in the functioning of the market. Evaluation of such activities is not clear in the economic literature. On the one hand, it depends on the form of the support, on the other hand on the applied theoretical and methodical approaches. Therefore, the main objective of the research conducted in 2011-2014 was to assess the efficiency of selected instruments of entrepreneurship development in the rural areas, using an objective and multicriteria approaches.

The studies were focused primarily on the European Union's financial instruments, influencing directly or indirectly the development of non-agricultural activities in the rural areas, which is a result of formation of entrepreneurial attitudes of the population. Application of purposive approach in such cases helped to assess the effectiveness of policies pursued by the European Union, i.e. to determine the degree of achievement of the overarching objective of convergence. The multi-criteria approach enabled to assess the technical efficiency of the transferred support and to determine the theoretical terms of the stability of the achieved results. The starting point of this study was the identification of all the instruments that can be used in the framework of the abovementioned policies to support the development of economic activities. The aim of the proceedings was to justify the fact that only partial assessment of the efficiency of selected instruments is possible. A wide range of instruments and the relation between them, as well as the diversity of theoretical approaches to the effectiveness of the policies make the objective and comprehensive assessment impossible.

\section{Theoretical background}

The support for business activity development can be implemented under various policies, defined according to the approach to the issue, the areas of support or the types of instruments used for intervention. However, each case, involves influence by the public sector on the production of private goods and services. The initiated activities also entail defined expenditures for the public-finance sector, which generally causes a reduction in the consumption of public goods. This creates the issue of efficient public fund utilisation, which is closely associated with the type of instrument applied in the support. The type of instrument applied in the support determines both the scale of assumed activities aiming to develop business activity and the scale of limiting the consumption of public goods. The application of defined instruments of support can be substitutive or complementary in relation to the production of public goods. The first case sees a situation where the increased public expenditures for enterprises create a proportional reduction in the expenditures for the production of public goods, while the second case sees the production of public goods as a potential factor in enterprise development.

Due to the aforementioned conditions, the professional literature includes a classification of the instruments supporting the development of enterprises. The broadest depiction distinguishes the following instruments (Gancarczyk, 2010): 
- direct - associated with financial transfers or transfers of specific financial services by the public sector to enterprises fulfilling the defined selection criteria;

- indirect - affecting all enterprises through their business environment.

Effectiveness is one of the criteria according to which assessment of the policy is made. Generally, it boils down to determining the degree of accomplishment of a given policy objectives (Krol, 2000; Pawlowski, 2000). In the case of policy to support the development of entrepreneurship, which uses instruments financed from the EU budget, the objective is economic convergence (Monfort, 2008). This results primarily from Regulation 1083/2006 of 12 July 2006, pursuant to which the actions taken by the EU funds should aim to achieve three main objectives, i.e. convergence, regional competitiveness and employment and territorial cooperation. In this regulation, convergence means improving conditions for growth and employment through increasing and improving the quality of investment in physical and human capital, development of innovation and knowledge society, adaptability to economic and social changes, protection and improvement of the environment and increasing administrative efficiency in least developed countries and regions.

The use of different instruments of regional and structural policy by the European Union for the development of entrepreneurship leads to convergence within the meaning of the Regulation. Transfers of funds contribute to the improvement of the situation in the indicated areas both at the national level and at the level of individual regions (Wasilewski 2011). But this is not synonymous with convergence understood in the context of economic theory (Quah, 1996; Solow, 1956; Romer, 1994). In this perspective, convergence is understood broadly as equalizing the level of development of regions (states), (Lazniewska et al., 2011). Bridging the development gap between the regions is thus an evidence of the convergence process, and not only improvement of the economic situation (Steger, 2006). However, the measurements of convergence, meaning the process of approaching the less developed regions to more develop ones in economic terms, use two approaches. In the first one, convergence is evidenced by decreasing differences between the indicators determining the level of economic development, while in the second compares the pace of development or economic growth. In econometric analyses, these two approaches are named respectively $\sigma$ and $\beta$ convergence (Bal Domańska, 2011). The choice of a particular type of convergence as a policy goal, however, should be preceded by a preliminary assessment of the potential to achieve each of them, in terms of the given policy.

The research problem concerned, i.e. the "efficiency of regional and structural policy instruments to support the development of entrepreneurship" is quite controversial. The soformulated problem demonstrates the active involvement of the state in economic processes and refers the concept of "efficiency" to measures undertaken by the state (Stringham, 2001; North, 2005; Weingast, 2005). Such an approach to economic development is criticized in the economic literature, in particular by mainstream representatives. However, active state economic policy is nothing new. Certain economists expressed a need for state intervention in economic processes, at the same time creating a theoretical basis. Mercantilists, who argued in the $17^{\text {th }}$ and $18^{\text {th }}$ century that the state should be closely involved in supporting the development of industry and trade, are a good example (Landreth, Colander, 2005). The EP 2015 (62) 2 (437-452) 
mercantilist concept of the role of the state, however, was strongly criticized by Smith and the followers of his classical approach to the economy (Landreth, Colander, 2005). Such a situation persisted up to the time of Keynes, who used certain concepts of mercantilism to demonstrate the significant role of the state in economic development.

The theory of welfare determines the easiest way for the economy to achieve Pareto efficiency. However, this is only possible under perfect market conditions. In practice, the correct functioning of the market, however, is distorted, which may lead to inefficient trade, production or its structure. These distortions occur due to market failures (Stiglitz, 2004), which include:

- competition failure,

- failure resulting from the existence of public goods,

- failure resulting from externalities,

- market incompleteness,

- asymmetric information,

- unemployment, inflation, imbalance.

In general, the economic literature suggests that any form of intervention, which may also include EU financial support to SMEs, slow down the efficient allocation of resources. Nevertheless, they can be a key driver for economic growth, as was the case in China. In accordance with Murrell (2005), the dual economy model plays such a role. As a matter of fact, the use of different intervention forms strengthens "marginal" efficiency. In relation to the New Institutional Economics, this means a temporary approval for a set of informal rights allowing for sub-marginal production. However, it provides social protection (Coase, 1960) for entities which would lose the most due to reforms, i.e. transition to a purely market economy (Lau et al., 2000). As a matter of fact, the result is a slowdown in the said reallocation, but - according to neo-institutionalists, it allows to gain time to develop protection mechanisms for market transactions. Given the social aspect of the dual economy, it can be said that certain solutions can be applied also in Poland. In fact, the use of such mechanisms is well-founded in the Constitution of the Republic of Poland, which defines the state economic system as a "social market economy". However, assessing policy efficiency in accordance with dual approach criteria would necessitate the determination of a degree to which the policy instrument concerned supports entities which would lose the most in the absence thereof. This in turn implies a need to establish criteria for the classification of entities to a so-called "group of losers".

\section{Methodical approach}

The econometric model of $\beta$-convergence (Abreu et al., 2005), adapted to the level of a county, was used to identify the processes of local convergence. This approach, in turn, implies the use of specific indicators and the structure of the analysis. The analysis of the convergence of regions and countries adopts the level of GDP or GDP per employee 
as a measure of the level of development. At the local level (county), such measures, unfortunately, cannot be applied. Therefore, assessment of the level of development of counties, and then the processes of equalization of these levels, uses the level of own income $^{3}$ of the county per 1 inhabitant of working age. It should be noted that the size of this category of income is quite often used in research on local development. It is the function of income obtained in the county, such as income of individuals, legal persons or income on their property or land. These revenues are therefore a function of income received from all factors of production located in the unit.

The initial stage of the study involved descriptive and comparative analysis of the state and changes in rural counties' own income in various systems determined by the level of this income category and the scale of the use of instruments to support the development of entrepreneurship financed from the budget of the European Union. The next stage was to analyze the size of own income depending on the amount of funds received in the county from the budget of the European Union under the Operational Programme Human Capital, Innovative Economy, the Regional Operational Programme and the Programme Development of Eastern Poland, per one worker of working age. As part of these programmes, many activities could be classified as direct or indirect instruments to support entrepreneurship in rural areas. In this case, the median size was also used as a criterion of the grouping.

The next stage of the research was to analyze the Gini coefficients, which are used to determine the level of diversity of objects in the population in terms of specific characteristics. The purpose of these coefficients was to increase knowledge about the process of local development and verification of the results of the analysis of basic statistics characterizing changes in own income per one inhabitant of working age.

The efficiency of regional and structural policy instruments to support the development of non-agricultural economic activities was assessed in respect of financial transfers from the EU budget through the Regional Operational Program (ROP), Innovative Economy Operational Program (IEOP), Human Capital Operational Program (HCOP) and others. While assessing the efficiency of financial support, both direct and indirect non-refundable support, which influenced the development of SMEs, was examined. Furthermore, the assessment of these instruments received by far the most attention in the study. However, such an approach was taken, because the EU budgetary period had finished, thus a need to assess the effects of the policy pursued in various aspects. The study of efficiency involved descriptive and comparative analysis of the state and changes of private and micro-enterprise number in rural counties' in various aspects determined by the scale of EU financial support for the development of entrepreneurship. The analysis is also focused on the relationships between this support and the employment and unemployment in rural counties. The criterion for grouping was the median and quartile value of the support per one inhabitant in working age. Finally the correlation and simple regression analysis were

3 The incomes and public support were expressed in Polish złoty (PLN). The exchange rate is about 4.2 PLN for 1 EUR

EP 2015 (62) 2 (437-452) 
utilized for the assessment of the impact of financial support scale on the county budget revenues and creation of new businesses and jobs.

The above analyses use the data from Central Statistical Office (CSO), Local Data Bank, for 2004-2013 for 1,529 rural counties. The population of this group of counties was without the units with own income in excess of the average value of income by more than 3 standard deviations. These were mainly counties obtaining substantial income from compensation for mining damage and those of typical tourist profile.

\section{Effectiveness of EU financial support - aspect of local convergence}

In the study period, i.e. in 2004-2011, the nominal own incomes per 1 inhabitant showed an upward trend. The break in the trend occurred in 2009, which was associated with the financial crisis in Europe. However, in the next two years after the collapse there was again an increase in income. In this context, it can be concluded that both the market conditions, as well as state-led policies were conducive to the development of rural areas and contributed to the relatively rapid overcoming of the negative effects of the financial crisis. The observed trends and the course of changes in the level of own income are therefore prerequisite to finding that the policy pursued to support the development of entrepreneurship, including based on various instruments financed by the European Union, does not contribute to equating the level and pace of development at the local level. However, one should note that this process of equating the development in the local system does not have to be the goal of this policy. In addition, slower income growth for low-income counties can be explained in the context of the Williamson's hypothesis (Williamson 1965). According to it, they still have not reached a certain level of economic development to significantly accelerate the rate of development.

Considering the impact of the measures from the budget of the European Union on local economic development, one should pay attention to changes in own income of counties in groups differing in terms of the level of absorption of these measures by the local community ${ }^{4}$ (Figure 1). Launching in 2007 of new programmes created quite wide possibilities for people to establish new businesses and extend existing businesses. However, the European Commission introduced the need to engage own capital as a condition of assistance. As a result, larger scale of the use of funds was in counties receiving higher own income in the period 2004-2007 (Figure 1), i.e. in units where people and businesses obtained higher incomes. In other words, entities had greater opportunities to engage own funds in establishing or developing business ventures. However, by 2007, own income of both groups of counties steadily increased, and the difference in nominal terms remained at a constant level. Since 2008, i.e. almost from the start of the programmes, counties with greater use of EU aid begun to obtain more and more advantage in terms of their incomes. At the same time there was a smaller decrease in their income as a result of the financial crisis. It can therefore be assumed that the scale of EU support had a significant positive impact on own income of rural counties. However, the use of various support programmes

4 The criterion was the median of income obtained in individual counties from operational programmes referred to in the methodical chapter, calculated per 1 inhabitant of working age. 
did not initiate the process of equating income of counties and even lead to increase in differences at the local level. Changing the criteria for the distribution of the support measures could counteract the increasing differences in the pace of economic development of counties. However, one must bear in mind other barriers to economic development when taking this type of action. Administrative increase in allocation of funds to units with lower incomes may lead to a significant reduction in the efficiency of support due to the presence of these barriers. On the basis of changes in own income, one can also draw a preliminary conclusion that the possibility of closing the gap in local development in rural areas with the help of existing policy instruments to promote entrepreneurship is generally very limited, or even non-existing. This does not undermine earlier claims regarding the positive impact of these instruments on the income received regardless of its initial level.

Coefficients of variation of own income of counties takes large values in both the group with low and a relatively high use of EU funds (Figure 2). Higher levels of internal diversity, however, are characteristic of the group with a high level of use of these resources. Since 2005, changes in diversification of counties are similar in both groups. However, in recent years there has been a much greater increase in income volatility in the group of counties with high levels of use of EU funds. One can say with high probability that this was the effect of isolating the group of counties with high incomes as a result of, inter alia, the impact of EU support. However, the analysis of counties diversification depending on the level of this support does not confirm the process of aligning the pace of local development.

Figure 1. Own income of rural counties in 2004-2011, by groups differed in terms of the use of EU funds under operational programmes involving support for the development of entrepreneurship.

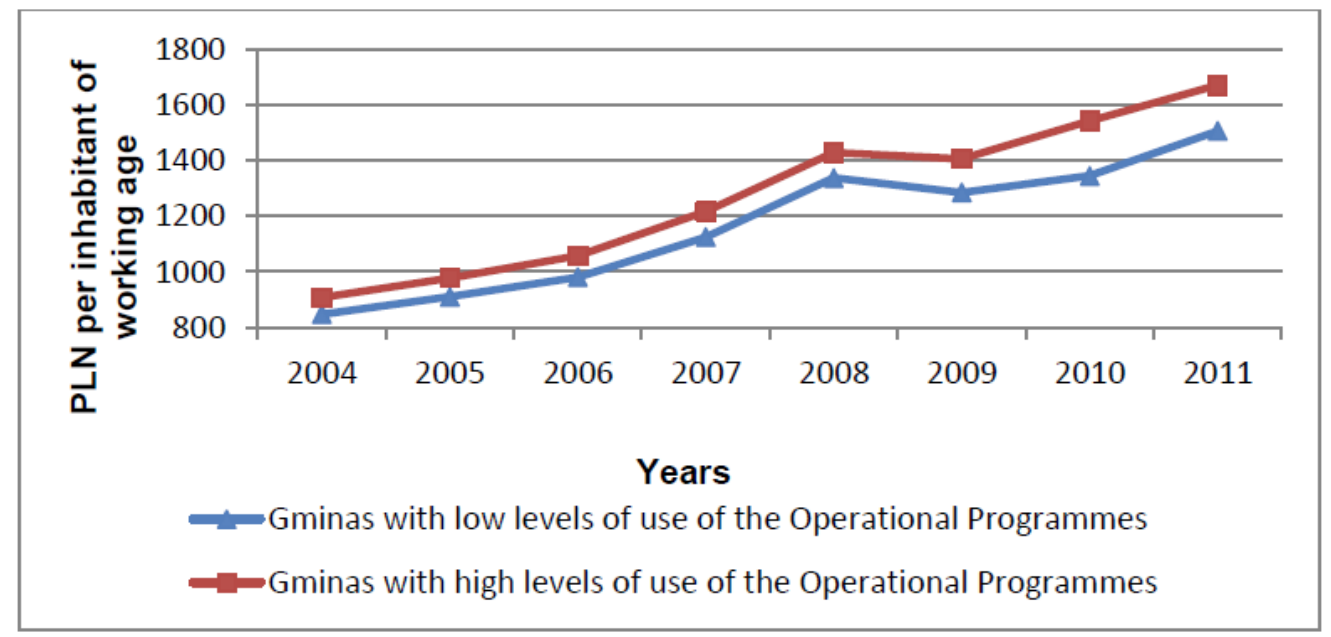

Source: own calculation based on data from CSO Local Data Bank. 
Figure 2. Coefficients of own income diversification in rural counties in 2004-2011, by groups differed in terms of the use of EU funds under operational programmes involving support for the development of entrepreneurship.

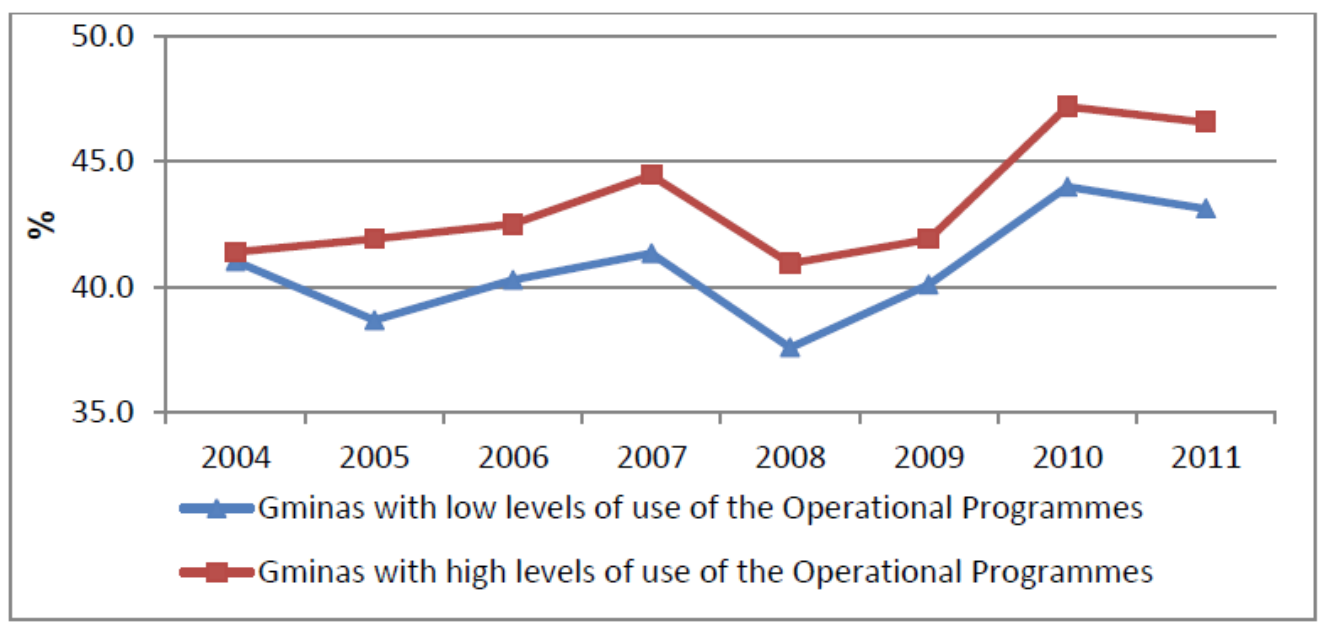

Source: own calculation based on data from CSO Local Data Bank.

The analyses of diversification of own income of counties do not give a complete picture of occurring changes. The results in many cases led to conclusions of a fairly large or fairly high diversity of own income of counties per 1 inhabitant. These concepts in case of analysis of basic statistics are, however, relative and subjective in nature. In order to objectify the results we used Gini coefficients to assess income diversification of counties per 1 inhabitant of working age, as a measure of local economic development and, changes of this diversification. This will also allow verification of the previously obtained results.

Changes and relationships of Gini indices in groups of counties diversified in terms of the level of use of EU funds by the local community (Figure 3) were similar to the case of coefficients of variation for the income of these groups. Both groups showed a slight upward trend of the coefficient, which means widening the gap of income regardless of the level of support used. However, counties with higher use of those funds were also characterized by higher level of the Gini coefficient in the corresponding period, i.e. they were more diverse in terms of their income. Analysis of changes in the Gini coefficient confirms the lack of impact of the EU funds absorbed by the local community on bridging the differences in the level of local development. These measures affect rather the widening of the gap. One can also say that they favour particularly the development of the most developed counties. However, taking into account the relatively low level of Gini coefficients and widening of the gap, one should confirm the thesis formulated earlier that a significant portion of the underdeveloped rural counties have not yet reached an adequate level of development in order to effectively use public support to significantly accelerate the rate of growth. 
Figure 3. Gini indices for own income per inhabitant of working age in rural counties in 2004-2011, by groups differing in terms of the use of EU funds under operational programmes involving support for the development of entrepreneurship.

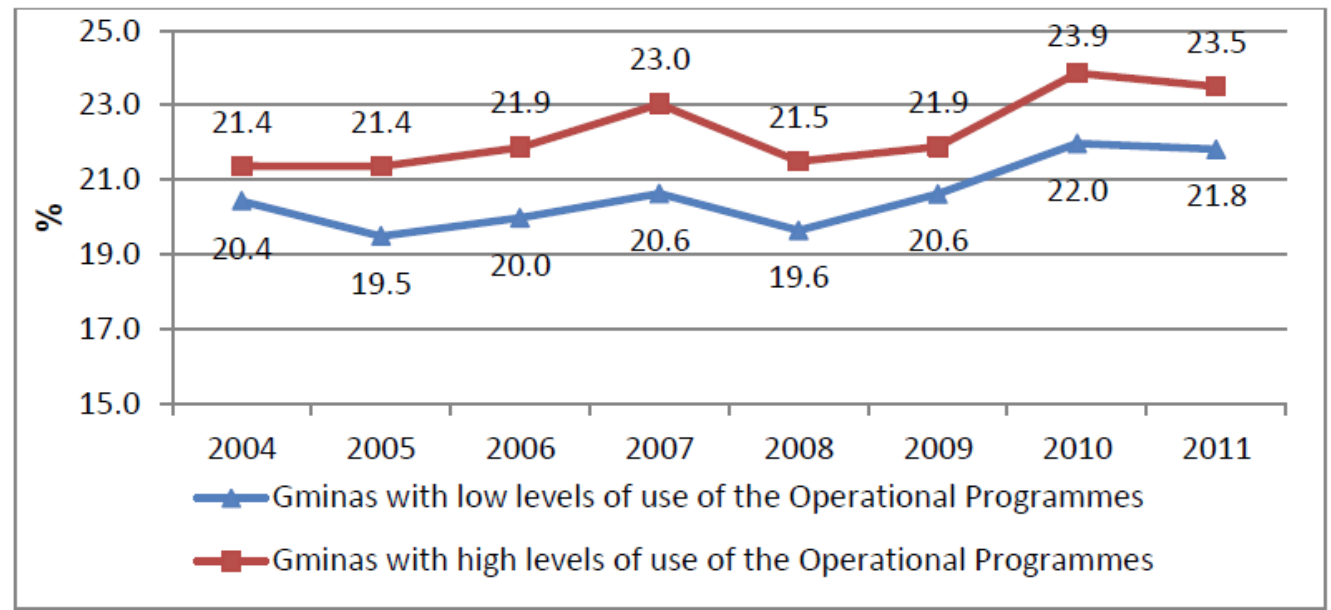

Source: own calculation based on data from CSO Local Data Bank.

Analysis of basic statistics and Gini indices for own income confirms the diversification of rural counties and the deepening of existing differences associated with the isolation of a group of counties with high incomes and a higher rate of growth. The relatively low values of the Gini coefficient show, however, that the variation is not too large. If one also takes into account the lack of a clear acceleration of the rate of development in the least developed counties, it can be concluded that a significant proportion of counties has not yet reached the critical level of development, beyond which the rate will significantly increase. The structural and regional policy, focused on the use of financial instruments, has no positive impact on reducing inequalities in local development. However, this does not mean the absence of a positive effect on income growth and slowing down the rise of differences.

The analysis of basic statistics and the Gini indices does not give a complete picture of the process of aligning the level and pace of development of counties. It is rather an analysis of differentiation, based on which one can define some rationale of this process. In order to verify or rather extend the results obtained, a method of unconditional beta convergence has been used. This method allows determining whether the counties with low levels of income are catching up in terms of their growth with counties with higher income and determine the time in which the existing differences will be reduced by half. Analysis of changes in own income, carried out by the unconditional beta convergence shows that the phenomenon occurs of local convergence among counties - determined based on changes in own income. 
Table 1. The results of the regression analysis for the unconditional beta convergence for own income per inhabitant of working age (2004-2011) by groups differing in terms of the use of EU funds under operational programmes involving support the development of entrepreneurship.

\begin{tabular}{|l|r|r|r|r|}
\hline \multicolumn{1}{|c|}{ Specification } & $\begin{array}{c}\text { Value of regression } \\
\text { coefficient }\end{array}$ & Standard error & P-value & Level of significance \\
\hline Counties with low levels of use of Operational Programmes \\
\hline $\ln (\mathrm{DW})$ it-1 & 0.31782 & 0.070902 & $7.38 \mathrm{E}-06$ & \\
\hline \# observation & 3825 & & & \\
\hline AR(2) & -0.6956774 & & 0.24332 & \\
\hline Sargan test & 50.51734 & & $5.00 \mathrm{E}-06$ & \\
\hline Counties with high levels of use of Operational Programmes \\
\hline ln (DW)it-1 & 0.416062 & 0.081761 & $3.61 \mathrm{E}-07$ & \\
\hline \# observation & 3820 & & & \\
\hline AR(2) & 0.5279689 & & 0.29876 & \\
\hline Sargan test & 56.5419 & & $4.70 \mathrm{E}-07$ & \\
\hline
\end{tabular}

Source: calculation of Marcin Gospodarowicz (Wasilewski, 2013) based on data from CSO Local Data Bank.

The impact of regional and structural policy on processes of aligning counties in terms of economic development is highlighted by the results obtained from the model of unconditional beta convergence for groups of counties differing in terms of the level of absorption of the different EU funds aimed at the development of entrepreneurship (Table 1 and Table 2). The analysis shows that convergence process occurred regardless of the level of funds obtained from the European Union. The group of counties with high absorption rate achieved the rate of convergence at nearly 5\% per year, which was 1 percentage point higher than in counties with small-scale use of these funds. Moreover, in this group, the period of halving the distance to the long-term equilibrium state was less than 14 years and was shorter by more than 3.5 years than in counties with low levels of absorption. This means that the higher level of financial support in the framework of the policies has a significant impact on the rate of convergence, in conditions of increasing diversity.

Table 2. Rate of unconditional convergence of type $\beta$ and the period of halving the difference in own income in 2004-2011, by groups differing in terms of the use of EU funds under operational programmes involving support the development of entrepreneurship.

\begin{tabular}{|l|r|r|}
\hline \multicolumn{1}{|c|}{ Specification } & \multicolumn{1}{|c|}{$\begin{array}{c}\text { Beta-convergence } \\
\text { coefficient }\end{array}$} & Half-life \\
\hline Counties with low levels of use of Operational Programmes & 0.0394 & 17.6 \\
\hline Counties with high levels of use of Operational Programmes & 0.0497 & 13.9 \\
\hline
\end{tabular}

Source: calculation of Marcin Gospodarowicz (Wasilewski, 2013) based on data from CSO Local Data Bank. 


\section{Local efficiency of financial support from the EU budget at the local level}

The chapter on methodology indicates that research covered 1,529 rural counties. In 20072013, these counties received about PLN 13.1 billion within the framework of different projects under, among others, the Regional Operational Programmes (ROP), the Human Capital Operational Programme (HCOP), the Innovative Economy Operational Programme (IEOP). Most of the funds, however, were transferred under the Regional Operational Programmes. Nearly $63 \%$ of the total EU budget designated for the analysed rural areas was spent on measures under these programmes, which included both direct and indirect support for the development of economic activities within the framework of infrastructure projects.

Research shows that each county received nearly PLN 1.9 thousand per capita of working-age population on average. However, the median value was below PLN 1.1 thousand, meaning that the vast majority of counties received support below the average for these areas. $25 \%$ of the examined counties obtained less than PLN 492 per capita of working-age population, and further $25 \%$ of counties - above PLN 2.2 thousand, i.e. slightly more than the average. Undoubtedly, the received financial assistance varied significantly, which is proved by the coefficient of variation that reached $251 \%$.

While analysing an increase in the absolute number of economic entities in county groups with different levels of financial support (Figure 4), it can be concluded that the relative level of financial transfers from the EU budget played an important role in launching economic activities by physical persons. In 2007-2013, i.e. the effective period of the financial instruments concerned, a larger increase in the number of economic entities was observed in county groups with a greater level of support. Quartiles 1 and 4 are significantly different. Throughout the effective period of support, the number of these entities in the latter increased by as much as 6 percentage points more. At the same time, it should be noted that the number of economic entities grew more in county groups, in which the initial number of the entities was higher. Having regard to the increase in the number of private economic entities, EU financial support can be considered as a quite efficient instrument. Nevertheless, despite the positive impact on the development of economic activities, further financial support under the same conditions can lead to excessive diversity in the development of economic activities between rural areas.

Similar relations, as in the case of private economic entities, were observed between an increase in the number of micro-enterprises and the level of EU financial support. However, due to data availability, the analysis covered 2009-2013 in this case. Thus, the period began with the year which brought the break in the upward trend in the number of entities due to the financial crisis. However, the number of entities grew much more in county groups with medium-high and high levels of support (Figure 4). Nonetheless, the difference in the growth between extreme, in terms of the level of support, county groups was only 2.1 percentage points. At the same time, it should be noted that the smallest growth in the number of micro-enterprises was not observed in county groups with the lowest level of support, but rather in those with medium-low support (quartile 2). The growth in the number of micro-enterprises in 2009-2013 slightly accelerated their average annual growth 
rate, as opposed to private enterprises. Nevertheless, having analysed this indicator, it can be stated that it is a rapidly developing sector, especially with financial support from the EU budget.

Among others, EU policy aimed at increasing employment and reducing unemployment. When assessing the efficiency of financial support, changes caused in rural areas in these fields must therefore be taken into account. Trends in employment changes were quite similar in nature to changes in the development of economic activities in the areas concerned. In 2007-2012, the share of the employed in the total number of working-age population decreased. However, in absolute terms, employment in rural areas increased by $10.7 \%$ (Figure 4). This employment growth was observed in all county groups, regardless of the level of support. Nevertheless, it was greater in counties with a higher level of EU support. Research shows that the difference between extreme, in terms of the relative level of support, county groups was as much as 11 percentage points, meaning that public funds were a relatively strong driving force for the recruitment of new staff, although they were insufficient to create conditions, in which these growing labour resources would be fully utilised. It should also be emphasised that the fastest growth in employment was observed in counties, in which its level was higher. In view of the above, it can be concluded that the diversity of rural areas in terms of the utilisation of labour resources increases. Nonetheless, the criteria used to distribute public financial support foster a kind of rural economic polarisation.

During Poland's membership in the European Union, two characteristic periods in unemployment changes can also be distinguished. In 2004-2008, there was a systematic and quite dynamic drop in the share of the unemployed in the total number of working-age rural population. In 2009, the financial crisis brought the upward trend that lasted until 2013. The unemployment rate increased relatively in all counties, regardless of the level of the support obtained from the EU budget. Unemployment growth in the effective period of the said policy instruments was observed not only in relative, but also in absolute terms (Figure 4). Nevertheless, changes in the number of the unemployed were in line with the share of the unemployed in the total number of working-age population, since a high level of support slowed down unemployment growth. In the period concerned, the number of the unemployed increased by 1 percentage point less in counties with the highest level of support than in counties in which this support reached the lowest level and by nearly 4 percentage points less than in counties with medium-high support. Unfortunately, a significant slowdown in unemployment growth is not observed in the case of the lower level of financial transfers from the EU budget. 
Figure 4. Change in local economic in county groups with different levels of EU support per capita of working-age population

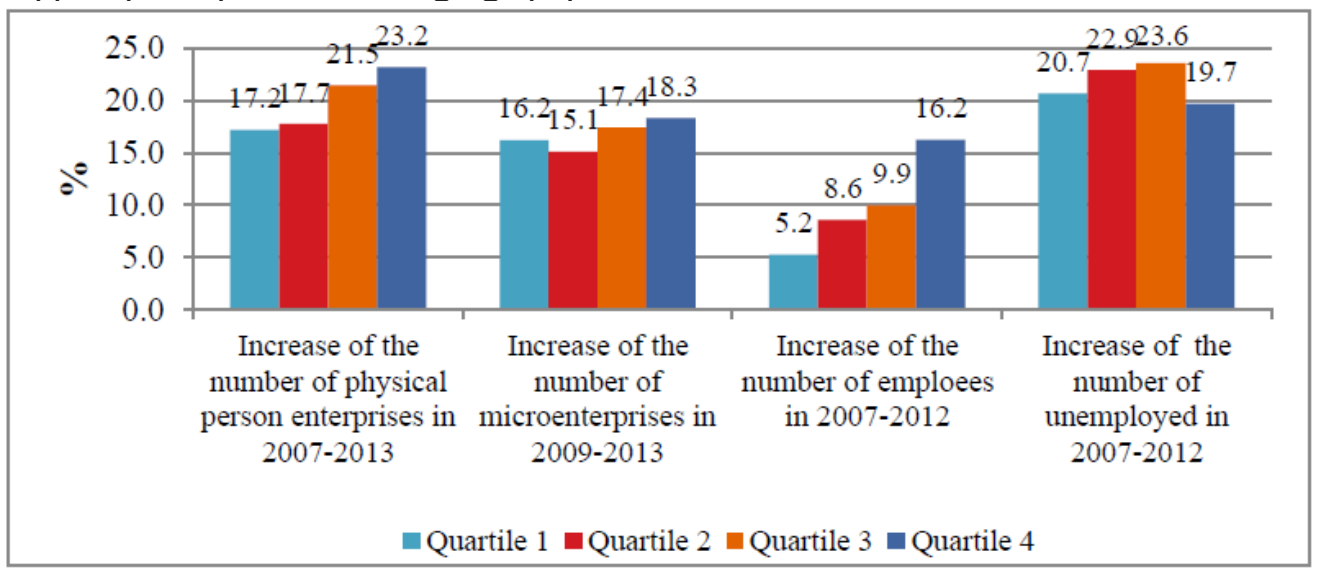

Source: Own calculations based on CSO data.

\section{Summary and conclusions}

The structural and regional policies focused on the use of financial instruments have no positive impact on reducing inequalities in local development. This conclusion follows from the analysis of basic statistics and Gini indices. It acknowledges the increase in diversity of counties in terms of economic development, regardless of the instruments used. Studies have confirmed to some extent, somewhat different effects of individual instruments on the differentiation of the pace of development. The results provide evidence for a thesis that the funds transferred under programmes involving direct and indirect support for enterprises contribute to accelerating the widening of the gap in local development.

The growing diversity of counties in terms of the level of development, determined on the basis of the analysis of basic statistics and Gini coefficients, does not mean the absence of the process of reaching the state of long-term equilibrium by counties with lower levels of development. This way, the process of aligning the territorial units in terms of the pace of development and economic growth is accounted for in the statistical models of unconditional beta convergence. The analyses conducted with this method show in turn, that there is a process of local convergence among rural counties, measured by own revenues of counties per inhabitant of working age.

In view of the existing economic theories, the fully positive assessment of the efficiency of public financial support can be justified only if these funds are used for purposes related to the development of technical and social infrastructure. However, there are different opinions on funds directly supporting enterprises in their day-to-day operations and investment activities. This instrument is in fact considered as a form of state interventionism, which can destroy free competition, thus destabilizing the market. However, this is the case when subsidies cause a drop in the prices of products manufactured by an enterprise. In accordance with certain economists, intervention instruments have rather short-term effects at the macro level. 
In their opinion, if public funds do not reach the most efficient entities, the market in the long run will make corrections and efficiently allocate resources.

However, based on empirical research on the impact of EU funds, which can be classified as instruments to directly or indirectly support the development of entrepreneurship in rural areas in 2007-2013, on economic processes, it is difficult to set a timeframe within which they will be reallocated to the most efficient entities. As a point of fact, they bring both measurable and positive economic effects in the current period. Analyses show that the higher level of support from the EU budget accelerates an increase in the number of private enterprises, micro-enterprises and the number of the employees. Moreover, it slows down the processes of growth in the number of the unemployed.

However, the existing relations in question should not allow the conclusion to be drawn that a significant economic improvement in rural areas can only be achieved as a result of a significant increase in the level of support, since it is impossible in practice due to budgetary constraints existing at both EU and national levels. However, the presence of statistically significant relations proves the efficiency of the instrument concerned. It can therefore be applied to support small-scale development projects in relation to the least economically developed areas if such an economic development concept is pursued.

When considering the possibility of using public financial support as an instrument for rural economic development, certain negative aspects should be kept in mind. In 2007-2013, relatively higher financial resources were transferred to more economically developed municipalities. Although they had positive effects, i.e. they accelerated economic development, their distribution under the same conditions can lead to the further diversification of rural municipalities in terms of the level of development. Thus, the distribution criteria applied neither foster the implementation of balanced rural development, nor promote bridging the gap in this development. However, they can be retained if another national development concept is pursued, such as establishing the so-called central units or growth poles. What is more, the positive effects of public financial support can be observed in the short term, i.e. during the period of transfer. In accordance with the existing theory, their positive impact on the local economic situation is supposed to weaken in the long run. Having ceased the use of this form of assistance, other instruments under policy to support the development of entrepreneurship are to play a greater role. In this case, fiscal policy and reduced bureaucracy can gain importance.

\section{Literature}

1. Abreu, M., de Groot, H., Florax, M. (2005): A Meta-Analysis of $\beta$-Convergence: the Legendary 2\%, Journal of Economic Surveys, Wiley Blackwell, vol. 19, no. 3, pp. 389420.

2. Bal Domanska, B. (2011): Ekonometryczna identyfikacja $\beta$ konwergencji regionow szczebla NUTS-2 państw Unii Europejskiej, Acta Universitatis Lodziensis, Folia Oeconomica, no. 253, pp. 9, University of Lodz, Lodz.

3. Coase, R. (1960): The problem of social cost, Journal of Law and Economics, vol. 3, no. 1, pp. 1-44. 
4. Gancarczyk, M. (2010): Wsparcie publiczne dla MSP, Podstawy teoretyczne a praktyka gospodarcza, C. H. Beck, Warszawa.

5. Krol, M. (2000): Kierunki oddziatywania uwarunkowan na cele i srodki polityki zatrudnienia, Polityka Gospodarcza, no. 3, pp. 43-50.

6. Landreth, H., Colander, D. (2005): Historia Mysli Ekonomicznej, PWN, Warszawa, pp. 58-63.

7. Lau, L., Quian, Y., Roland, G. (2000): Reform Without Losers: An Interpretation of China's Dual-Track Approach to Transition, Journal of Political Economy, vol. 108, no. 1, pp. 120-143.

8. Lazniewska, E., Gorecki, T., Chmielewski, R. (2011): Konwergencja regionalna, Wydawnictwo Uniwersytetu Ekonomicznego w Poznaniu, Poznan.

9. Local Data Bank of the Central Statistical Office, Central Statistical Office of Poland, Warsaw, information portal, available at: www.stat.gov.pl

10. Monfort, P. (2008): Convergence of EU regions Measures and Evolution, Working papers $1 / 2018$, A series of short papers on regional research and indicators produced by the Directorate-General for Regional Policy, European Commission, Brussels, pp. 1-20.

11. Murrell, P. (2005): Institutions and Firms in Transition Economies, in: Menard, C., Shirley, M. (Edts.) Handbook of New Institutional Economics, Springer, Dordrecht, Berlin, Heidelberg, New York, pp. 688-690.

12. North, D. (2005): Institutions and the performance of economies over time, in: Menard, C., Shirley, M. (Edts.) Handbook of New Institutional Economics, Springer, Dordrecht, Berlin, Heidelberg, New York, pp. 22-23.

13. Pawłowski, G. (2000): Wykorzystanie analizy efektywności funkcjonowania instytucji publicznych $w$ aspekcie konkurencyjności regionów, Polityka Gospodarcza, no. 3, pp. 65-71.

14. Quah, D. (1996): Twin Peaks: Growth and Convergence in Models of Distribution Dynamics, Economic Journal, Royal Economic Society, vol. 106, no. 437, pp. 1045-55.

15. Romer, P.(1994): The Origins of Endogenous Growth, Journal ofEconomic Perspectives, American Economic Association, vol. 8, no. 1, pp. 3-22.

16. Solow, R. (1956): A contribution to the theory of economic growth, The Quarterly Journal of Economics, vol. 70, no. 1, pp. 65-94.

17. Steger, T. (2006): On the Mechanics of Economic Convergence, German Economic Review, vol. 7, no. 3, pp. 317-337.

18. Stiglitz, J. E. (2004): Ekonomia sektora publicznego, PWN, Warszawa.

19. Stringham, E. (2001): Kaldor-Hicks Efficiency and the Problem of Central Planning, the Quarterly Journal of Austrian Economics, vol. 4, no. 2, pp. 42.

20. Wasilewski, A.(Ed.),(2011): Instrumenty polityki regionalnej i strukturalnej wspierajace rozwoj przedsiebiorczosci na obszarach wiejskich, Prace Programu Wieloletniego, no. 14, IAFE-NRI, Warszawa.

21. Wasilewski,A.(Ed.),(2013): Skuteczność instrumentów polityki regionalnej i strukturalnej oddziałujacych na rozwój przedsiębiorczości, Prace Programu Wieloletniego, no. 77, IAFE-NRI, Warszawa, pp. 46-47. 
22. Weingast, B. (2005): The performance and stability of federalism: an institutional perspective, in: Menard, C., Shirley, M. (Edts.) Handbook of New Institutional Economics, Springer, Dordrecht, Berlin, Heidelberg, New York, pp. 152-156.

23. Williamson, J. (1965): Regional inequality and process of national development: a description of the patterns, Economic development and cultural change, vol. 13, no. 4, part II, pp. 1-84, University of Chicago press. 